\title{
Verano, verano: Performance Review
}

\section{Wilma Feliciano}

Verano, verano (2013), by Puerto Rican playwright Myrna Casas, revives the poetic realism of her first drama, Cristal roto en el tiempo (1960). Subsequent to Cristal, she experimented with non-realistic techniques such as the absurd, in La trampa (1964), and metadrama, in El gran circo eucraniano (1988). In these pieces, Casas relied on misunderstandings, caustic humor, and reversals to mock the social mores of middle-class misfits. In Verano, verano, perverse family dynamics unleash anguish, denial, and shame. Set in the beach house that once delighted the young family, the now dusty patio and weathered furniture symbolize their demise.

Structured in 26 short scenes that alternate between strained conversations, suppressed words, and monologues, the plot interweaves yesterday's secrets with today's melancholy. The characters, both the dead and those alive, exist in solitude and silence. Don Pablo, a womanizing patriarch, describes the maturation of his son Juan Pablo from a whimsical youth to an alienated recluse: "Fue fantasioso desde pequeño. Recuerdo que hasta hablaba

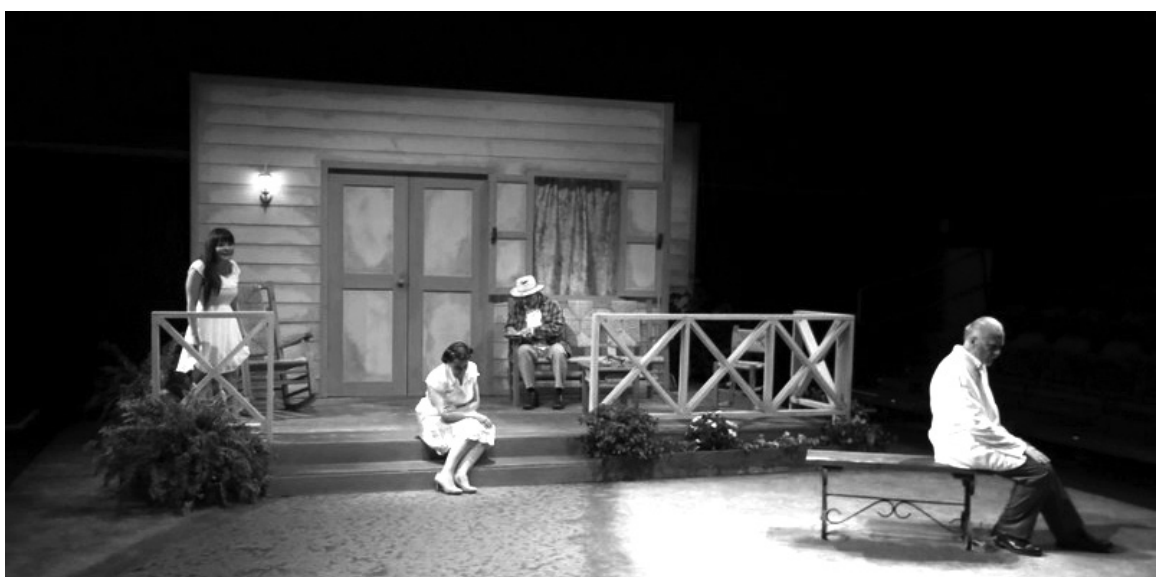

The unhappy family isolated in their common anguish. Photo: Gregorio Barreto. 


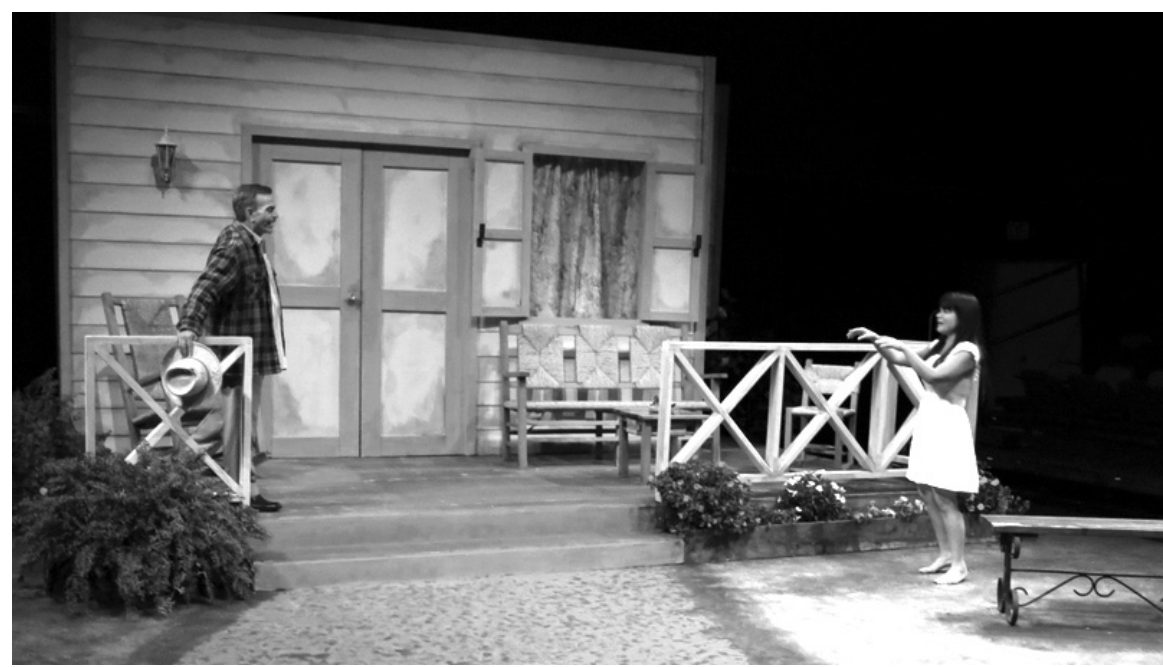

Celeste tries to amuse Juan, her father. Photo: Gregorio Barreto.

con amigos invisibles, quizás es preferible no enfrentarse a realidades tan amargas" (37). Juan talks only to Celeste, his invisible daughter, who comes back from the dead periodically to snatch snippets of the past.

Don Pablo blames his infidelity and his wife's rancor for the family's dissolution. Adriana cannot see her daughter, so she believes Juan's truncated talk evinces his mental illness and tries to evoke happy memories, but he silences her. His constant rejections drive Adriana to take a lover, but when Celeste sees them, Adriana imposes a code of secrecy on the confused child. Worse, Adriana always preferred her son Bobby and blames Celeste for not rescuing him from the ocean. The refrain of the well-known lullaby "Naranja dulce" softly intones the lament of the unloved child: "Dame un abrazo que yo te pido" $(44,53-54)$.

Along with the lullaby, other auditory and visual images underscored the tone of relentless grief in the production of Verano, verano at the Interamerican University of Arecibo, Puerto Rico, on November 13, 2013. Ocean sounds reinforced the beach setting. Modern music and children's songs harmonized past and present, while lighting changes and flashbacks moved the action. Don Pablo's elegant garb portrays him as a man of means. In contrast, his son's worn pants and tattered hat identify him with the jíbaros (peons) of Puerto Rico. Ironically, the white dresses of Adriana and Celeste suggest their innocence, as if life had dragged them to their dilemmas. Arguably the starkest image of decay was the fumigator on the dusty coffee table. Always visible but never touched or mentioned, the fumigator suggests a 


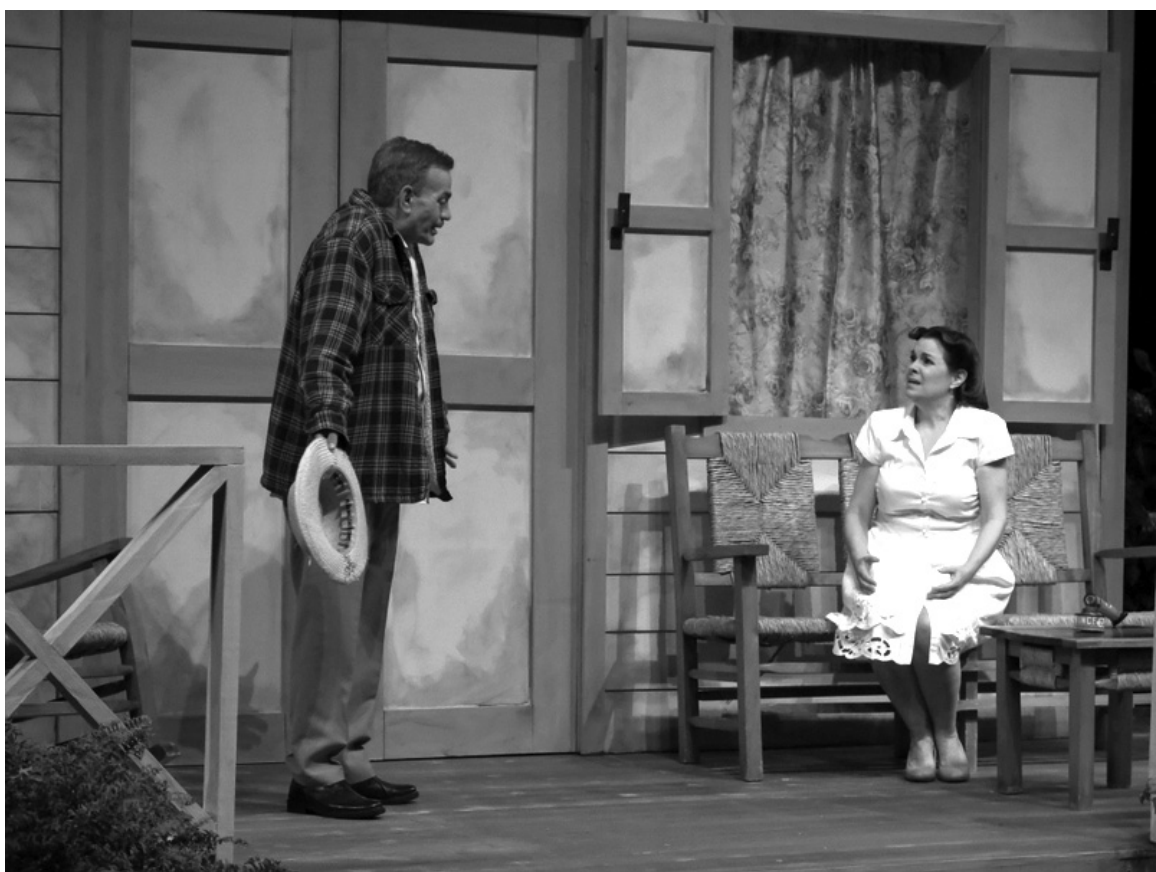

Juan Pablo and Adriana, an estranged marriage. Photo: Gregorio Barreto

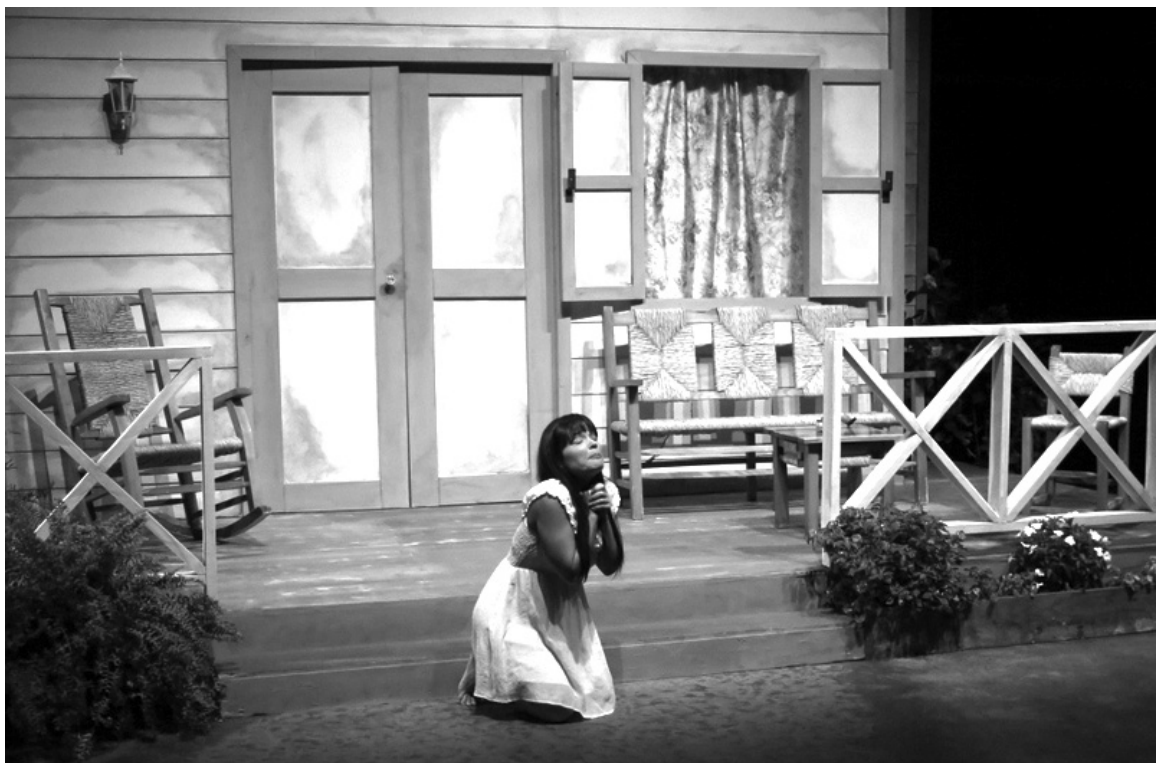

Celeste prays for Adriana's mother love. Photo: Gregorio Barreto. 
family infested by male privilege, which includes Don Pablo's philandering and Juan's insistence on silencing his wife and daughter. Even the memory of little Bobby destroying the sand castle portends his machismo and the family's fate. Juan's depression drowns them all in the same ocean that took the children and facilitated Adriana's suicide. Finally, the ironic title, Verano, verano, contrasts the warm happy days of youth with the icy bitterness of perpetual winter. The play ends as Celeste, recollecting blue skies, sings "Naranja dulce" and imagines that her mother loves her.

SUNY College at New Paltz 